Note

\title{
Pituitary Apoplexy Induced by a Combined Anterior Pituitary Test: Case Report and Literature Review
}

\author{
Fumio OTSUKA, Jingo KAGEYAMA*, Toshio OGURA** AND HiRofumi MAKINO \\ Department of Medicine III, Okayama University Medical School and *Department of Nursing, \\ School of Health Sciences, and ${ }^{* *}$ Health and Medical Center, Okayama University, Okayama 700-8558, Japan
}

\begin{abstract}
We report the case of a 31-year-old woman with a pituitary adenoma who suffered symptomatic pituitary apoplexy. The patient developed a severe headache $2 \mathrm{~min}$ after undergoing a combined anterior pituitary function (CAP) test. Emergent computed tomography revealed a hemorrhagic pituitary tumor with evidence of a small subarachnoid hemorrhage. The headache improved spontaneously within half a day. Transsphenoidal surgery was performed 4 days later. Histologic examination demonstrated that the tumor was an eosinophilic adenoma with areas of diffuse hemorrhage. Although pituitary apoplexy caused by endocrinological testing has been reported in only 28 patients, apoplexy caused by a CAP test has been reported in only 1 patient. All of the previous cases had pituitary macroadenomas, $69 \%$ of which were involved in suprasellar extension. Non-functioning adenomas $(24 \%)$ and prolactinomas $(24 \%)$ were the most often affected by endocrine stimulation tests. With respect to the stimulants of pituitary adenomas, gonadotropin-releasing hormone $(76 \%)$, TSHreleasing hormone $(69 \%)$, and insulin (34\%) were primarily responsible for the apoplexy. This case report with the literature review suggests that routine testing on pituitary function should be ordered cautiously given the risk of possible apoplexy.
\end{abstract}

Key words: Pituitary adenoma, Pituitary apoplexy, Endocrinologic stimulation tests, Combined anterior pituitary (CAP) test, Acromegaly

(Endocrine Journal 45: 393-398, 1998)

PITUITARY apoplexy is characterized by the sudden onset of headache, vomiting, visual impairment, diplopia, changes in the level of consciousness, and hormonal dysfunction. This condition is considered to be caused by hemorrhage or hemorrhagic infarction of a preexisting pituitary adenoma [1,2]. Although pituitary apoplexy following dynamic pituitary function testing has been previously reported [3-24], the etiology of the apoplexy has not been clarified. We report a patient with macroadenoma who developed pituitary apoplexy following dynamic pituitary

Received: September 18, 1997

Accepted: January 29, 1998

Correspondence to: Dr. Fumio OTSUKA, Department of Medicine III, Okayama University Medical School, 2-5-1 Shikata-cho, Okayama-city, Okayama 700-8558, Japan function tests, and discuss the causality of the manifestation of apoplexy from previous reports.

\section{Case Report}

A 31-year-old woman with a 1-year history of visual disturbances was referred to our hospital for evaluation of a suprasellar tumor detected by magnetic resonance imaging (MRI). The patient had experienced a weight gain of $10 \mathrm{~kg}$ and gradual enlargement of her feet and fingers over a 3-year period. She had suffered from amenorrhea since the age of 28 years, but suffered neither polyuria nor polydipsia. Physical examination revealed the following: height, $162 \mathrm{~cm}$; weight, $66 \mathrm{~kg}$; no typical acromegalic features but her feet and fingers were slightly enlarged; blood pressure, 110/70 $\mathrm{mm} \mathrm{Hg}$; 
heart rate, $60 \mathrm{bpm}$, regular; no focal abnormalities neurologically except bilateral hemianopsia; neither goiter, lymphadenopathy nor pretibial edema were observed. Skull roentgenogram demonstrated marked expansion of the sella. MRI revealed a large heterogeneous pituitary mass (area, $7.4 \mathrm{~cm}^{2}$ ) involving the optic chiasm and the left cavernous sinus (Fig. 1). Basal levels of various hormones are summarized in Table 1a. Serum GH, insulin like growth factor-1 (IGF-1), ACTH and PRL concentrations were increased. In contrast, gonadotropins and thyroid hormones were partially disturbed.

Combined anterior pituitary (CAP) testing with $1 \mu \mathrm{g} / \mathrm{kg}$ body weight of $\mathrm{CRH}, \mathrm{GH}$ releasing hormone (GRF), gonadotropin releasing hormone $(\mathrm{GnRH})$ and $200 \mu \mathrm{g}$ of TRH were planned to evaluate the patient's preoperative hormonal responses. But when $20 \mu \mathrm{g}$ of $\mathrm{CRH}, \mathrm{GRF}$, and $\mathrm{GnRH}$, and $100 \mu \mathrm{g}$ of TRH were actually administered during the $2 \mathrm{~min}$ after the injection, the patient complained of a severe headache followed by nausea and a feeling of chest oppression. The patient was alert and had no focal

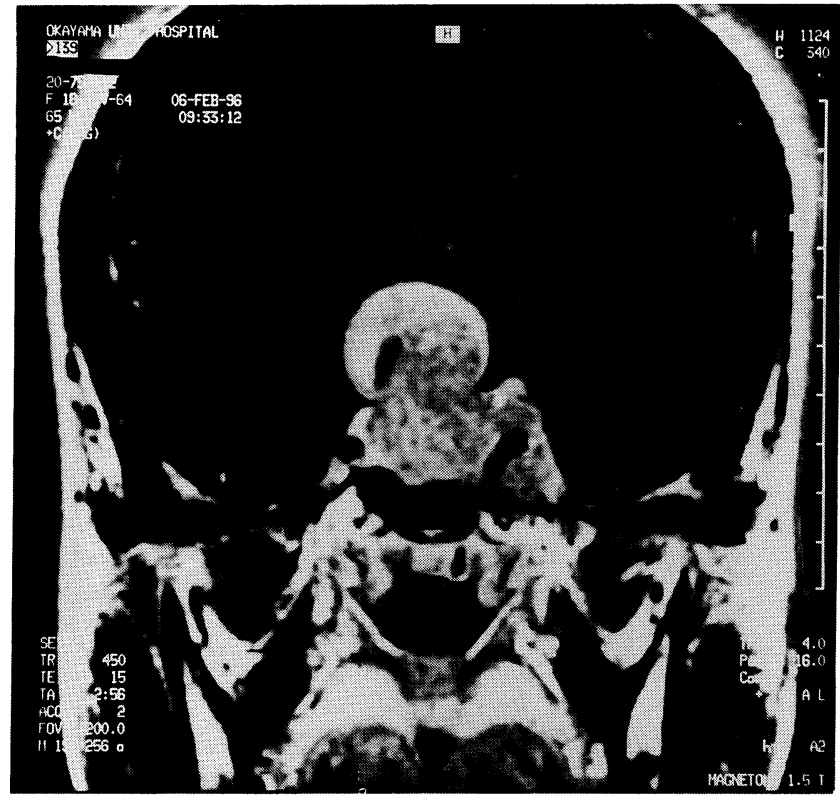

Fig. 1. Pituitary magnetic resonance imaging (MRI). Cranial MRI revealed a large pituitary mass involving the optic chiasm and left cavernous sinus. There was heterogeneous enhancement of the tumor with gadolinium.

Table 1a. Basic endocrinologic data on admission

\begin{tabular}{llrllr}
\hline ACTH & $77.2 \mathrm{pg} / \mathrm{mL}$ & $(4.4-48)$ & TSH & $0.53 \mu \mathrm{U} / \mathrm{mL}$ & $(0.55-4.8)$ \\
$\mathrm{GH}$ & $53.1 \mathrm{ng} / \mathrm{mL}$ & $(0.28-8.7)$ & FT3 & $3.31 \mathrm{pg} / \mathrm{mL}$ & $(4-5.8)$ \\
$\mathrm{PRL}$ & $61.3 \mathrm{ng} / \mathrm{mL}$ & $(<30)$ & FT4 & $0.86 \mathrm{ng} / \mathrm{dL}$ & $(1.03-2.21)$ \\
$\mathrm{LH}$ & $0.45 \mathrm{mIU} / \mathrm{mL}$ & $(1.5-5)$ & F & $12.5 \mu \mathrm{g} / \mathrm{dL}$ & $(5-21)$ \\
$\mathrm{FSH}$ & $2.24 \mathrm{mIU} / \mathrm{mL}$ & $(4-10)$ & IGF-I & $629 \mathrm{ng} / \mathrm{mL}$ & $(150-214)$ \\
\hline
\end{tabular}

FT3, free triiodothyronine; FT4, free thyroxine; F, cortisol; IGF-1, insulin like growth fact : -1 ; values in parenthesis indicate normal values.

Table 1b. Results of combined anterior pituitary (CAP) test

\begin{tabular}{lrccc}
\hline & & basal value & peak value & peak time $(\mathrm{min})$ \\
\hline $\mathrm{ACTH}$ & $(\mathrm{pg} / \mathrm{mL})$ & 44.8 & 71.3 & 30 \\
$\mathrm{~F}$ & $(\mu \mathrm{g} / \mathrm{dL})$ & 6.8 & 9.3 & 30 \\
$\mathrm{GH}$ & $(\mathrm{ng} / \mathrm{mL})$ & 61.2 & 147.2 & 30 \\
$\mathrm{TSH}$ & $(\mu \mathrm{U} / \mathrm{mL})$ & 0.71 & 8.13 & 30 \\
$\mathrm{PRL}$ & $(\mathrm{ng} / \mathrm{mL})$ & 59.3 & 110.7 & 15 \\
$\mathrm{LH}$ & $(\mathrm{mIU} / \mathrm{mL})$ & 1.61 & 6.52 & 60 \\
$\mathrm{FSH}$ & $(\mathrm{mIU} / \mathrm{mL})$ & 0.26 & 4.04 & 90 \\
\hline
\end{tabular}

F, cortisol. 


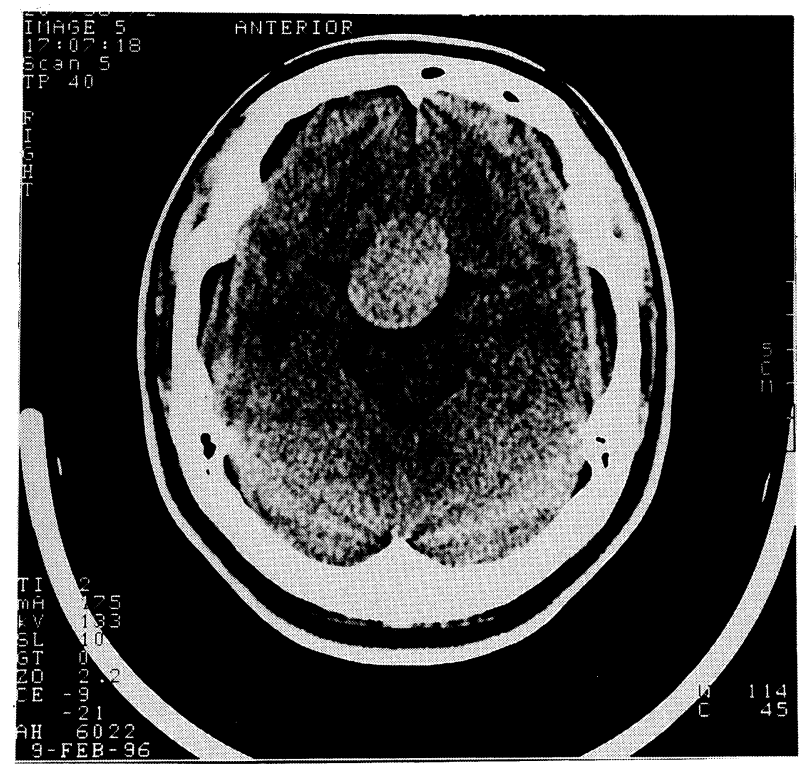

Fig. 2. Emergent cranial computed tomography (CT). Emergent CT revealed pituitary bleeding not only within the tumor but also around the tumor and in the subarachnoid space, suggesting pituitary apoplexy.

Emergent computed tomography (CT) revealed that the pituitary mass had enlarged (area, $8.7 \mathrm{~cm}^{2}$ ), and there was evidence of bleeding not only within the tumor but also around the tumor and in the subarachnoid spaces (Fig. 2). The severe headache continued for about half a day. Because the symptoms have gradually improved, emergent surgery was not performed. The results of the pituitary stimulation tests are shown in Table $1 b$, and reflect a hyperresponse of GH to GRH and poor responses of LH and FSH to GnRH.

Four days after the CAP test, transsphenoidal surgery was performed. There was evidence of a small hemorrhage around the tumor in the subarachnoid space. The tumor was soft and yellow and contained blood. The tumor was evacuated with a regular microsurgical suction tube, but was not resected because of the presence of tight adhesions to the cavernous sinus. Histological examination revealed that the tumor was an eosinophilic pituitary adenoma. Postoperatively, the patient's visual disturbance resolved and the PRL concentration was normalized, but since the gonadotropin response to $\mathrm{GnRH}$ remained attenuated and the basal GH concentration was still as high as $10 \sim 15 \mathrm{ng} / \mathrm{mL}$, she has been treated with self-injection of octreotide (100 $\mu \mathrm{g} /$ day) and replacement of estrogen and progesterone. Half a year after the surgery, her GH level has been lowered to $3 \sim 5 \mathrm{ng} / \mathrm{mL}$, and the IGF-1 level has settled to below $200 \mathrm{ng} / \mathrm{mL}$ one year after the start of the octreotide injection.

\section{Discussion}

The classic definition of pituitary apoplexy is the acute, life-threatening loss of pituitary function. Hemorrhagic infarction causing apoplexy most commonly occurs in the presence of a pituitary tumor but may also occur spontaneously in a normal gland [1, 2]. Since 1975, pituitary apoplexy induced by pituitary function testing has been reported in 28 patients (Table 2) [3-24]. All of the reported cases have involved macroadenomas, including 69\% (20 of 29 patients) with suprasellar extension of the tumor. Another common characteristic is the acute onset of symptoms after pituitary stimulation. Pituitary apoplexy developed within 3 days after the administration in all of the patients, and occurred within $30 \mathrm{~min}$ in $70 \%$ of the patients.

The relationship between the type of tumor and the stimulants with respect to the development of apoplexy has not been discussed in previous reports. We therefore analyzed this relationship in previous reports (Table 3 ). Of the apoplectic adenomas, prolactinomas $(24 \%)$ and growth hormone producing adenomas $(21 \%)$ were the most common, whose sequence was in keeping with that of frequency in pituitary adenomas [25]. Interestingly, apoplexy occurring in patients with non-functioning adenomas was also common (24\%). Bills et al. reported that $94 \%$ of patients with pituitary apoplexy had pituitary tumors demonstrable by $\mathrm{CT}$, and that null cell adenomas occurred more frequently (52\%) than functioning adenomas [1]. Among various stimulants, TRH is most likely to cause infarction and hemorrhage probably because of its vasoactive properties [10, $12,18]$. In our review of the literature, $\mathrm{GnRH}$, TRH and insulin stimulation were associated with the development of pituitary apoplexy (Table 3). With respect to GnRH, therapy with goserelin or triptorelin for the treatment of prostate cancer 
Table 2. Literature review of cases of pituitary apoplexy after pituitary function testing to assess pituitary adenoma

\begin{tabular}{|c|c|c|c|c|c|}
\hline Author (Year) & Age/Gender & Tumor & Size & Stimulants & nset of apoplexy \\
\hline Dunn (1975) & $22 / \mathrm{F}$ & GH-oma & macro & $\operatorname{Glc}(25 \mathrm{~g})+\operatorname{Ins}(0.3 \mathrm{U} / \mathrm{kg})+\mathrm{TRH}[400]$ & $2 \mathrm{~d}$ \\
\hline Silverman (1978) & $31 / \mathrm{M}$ & PRL-oma & macro+SS & Chlorpromazine $(25 \mathrm{mg})$ & $90 \mathrm{~m}$ \\
\hline Jordan (1979) & $21 / \mathrm{F}$ & ACTH-oma & macro & Dexamethasone(20 mg) & $3 \mathrm{~d}$ \\
\hline Cimino (1981) & $48 / \mathrm{M}$ & non-F & macro+SS & GnRH[100]+TRH[200] & $20 \mathrm{~m}$ \\
\hline \multirow[t]{4}{*}{ Drury (1982) } & $59 / \mathrm{F}$ & non-F & macro+SS & Gluca(1.5 mg)+GnRH[100]+TRH[200] & $5 \mathrm{~m}$ \\
\hline & $66 / \mathrm{M}$ & GH-oma & macro & TRH[200] & $10 \mathrm{~m}$ \\
\hline & $39 / \mathrm{F}$ & PRL-oma & macro+SS & GnRH+TRH & $2-3 \mathrm{~m}$ \\
\hline & $28 / \mathrm{M}$ & PRL-oma & macro+SS & GnRH+TRH & $15 \mathrm{~m}$ \\
\hline Bernstein (1984) & $48 / \mathrm{M}$ & non-F & macro & $\mathrm{GnRH}[100]+\mathrm{TRH}[200]+\operatorname{Ins}(0.1 \mathrm{U} / \mathrm{kg})$ & $5 \mathrm{~m}$ \\
\hline Korsic (1984) & $56 / \mathrm{M}$ & FSH-oma & macro+SS & GnRH[100] & $2 \mathrm{~h}$ \\
\hline Chapman (1985) & $39 / \mathrm{F}$ & PRL-oma & macro+SS & GnRH[100]+TRH[200]+Ins(0.15 U/kg) & $30 \mathrm{~m}$ \\
\hline \multirow[t]{2}{*}{ Yatsuzuka (1986) } & $20 / \mathrm{M}$ & PRL-oma & macro & GnRH[100]+TRH[500]+Ins(0.1 U/kg) & $?$ \\
\hline & $36 / \mathrm{M}$ & PRL-oma & macro+SS & $\mathrm{GnRH}[100]+\mathrm{TRH}[500]+\operatorname{Ins}(0.1 \mathrm{U} / \mathrm{kg})$ & $?$ \\
\hline Lever (1986) & $19 / \mathrm{F}$ & GH-oma & macro & TRH[200] & $2 \mathrm{~m}$ \\
\hline Shirataki (1988) & $50 / \mathrm{F}$ & GH-oma & macro+SS & Bromocriptine (2.5 mg) & $2 \mathrm{~h}$ \\
\hline Harvey (1989) & $50 / \mathrm{M}$ & $?$ & macro & $\operatorname{Ins}(0.15 \mathrm{U} / \mathrm{kg})$ & during \\
\hline Arafah (1989) & $41 / \mathrm{F}$ & PRL-oma & macro+SS & GnRH[100] & $60 \mathrm{~m}$ \\
\hline Kimura (1989) & $14 / \mathrm{M}$ & non-F & macro+SS & GnRH+TRH+Ins & $20 \mathrm{~m}$ \\
\hline Yada (1992) & $60 / \mathrm{F}$ & $?$ & macro+SS & GnRH[100]+TRH[500]+Ins(5 U) & $10 \mathrm{~m}$ \\
\hline Masson (1993) & $54 / \mathrm{M}$ & FSH-oma & macro+SS & GnRH[100] & $20 \mathrm{~m}$ \\
\hline Fujiwara (1993) & $67 / \mathrm{F}$ & GH-oma & macro+SS & $\mathrm{ACTH}+\mathrm{GnRH}$ & $30 \mathrm{~m}$ \\
\hline Haakens (1994) & $48 / \mathrm{M}$ & FSH-oma & macro+SS & GnRH[100]+TRH[500]+Ins $(0.1 \mathrm{U} / \mathrm{kg})$ & $15 \mathrm{~m}$ \\
\hline Vassallo (1994) & $54 / \mathrm{M}$ & non-F & macro+SS & GnRH[100]+TRH[500] & $10 \mathrm{~m}$ \\
\hline Frankart (1995) & $69 / \mathrm{M}$ & $?$ & macro & $\mathrm{GnRH}[100]+\mathrm{TRH}[200]+\mathrm{CRH}[100]+\mathrm{GRH}[1 / \mathrm{kg}]$ & $30 \mathrm{~m}$ \\
\hline \multirow[t]{2}{*}{ Masago (1995) } & $81 / \mathrm{M}$ & $?$ & macro+SS & GnRH[100]+TRH[200]+levodopa(500 mg) & $2 \mathrm{~h}$ \\
\hline & $64 / \mathrm{M}$ & FSH-oma & macro & GnRH[100]+TRH[200] & $2 \mathrm{~d}$ \\
\hline \multirow[t]{2}{*}{ Abe (1995) } & $48 / \mathrm{M}$ & non-F & macro+SS & GnRH+TRH+Ins & $4 \mathrm{~m}$ \\
\hline & $74 / \mathrm{F}$ & non-F & macro+SS & GnRH & $2-3 \mathrm{~m}$ \\
\hline Current patient & $31 / \mathrm{F}$ & GH-oma & macro+SS & $\mathrm{GnRH}[20]+\mathrm{TRH}[100]+\mathrm{CRH}[20]+\mathrm{GRH}[20]$ & $2 \mathrm{~m}$ \\
\hline
\end{tabular}

Glc, glucose; Ins, insulin; GnRH, gonadotropin releasing hormone; GRH, growth hormone releasing hormone; Gluca, glucagon; non-F, non-functioning tumor; SS, suprasellar extension; macro, macroadenoma; $d$, day; h, hour; m, minute; brackets include the value of $\mu \mathrm{g}$.

Table 3. Summary of literature review of cases of pituitary apoplexy associated with endocrinologic testing

\begin{tabular}{lccccccc}
\hline $\begin{array}{l}\text { Pituitary tumor } \\
\text { (Number of cases) }\end{array}$ & $\begin{array}{c}\text { GH-oma } \\
(6)\end{array}$ & $\begin{array}{c}\text { PRL-oma } \\
(7)\end{array}$ & $\begin{array}{c}\text { FSH-oma } \\
(4)\end{array}$ & $\begin{array}{c}\text { ACTH-oma } \\
(1)\end{array}$ & $\begin{array}{c}\text { non-F } \\
(7)\end{array}$ & $\begin{array}{c}\text { unknown } \\
(4)\end{array}$ & $\begin{array}{c}\text { total } \\
(29)\end{array}$ \\
\hline $\begin{array}{l}\text { Hypothalamic stimulants } \\
\text { GnRH }\end{array}$ & 2 & 6 & 4 & - & 6 & 3 & 21 \\
TRH & 4 & 5 & 2 & - & 6 & 3 & 20 \\
GHR & 1 & - & - & - & - & 1 & 2 \\
CRH & 1 & - & - & - & - & 1 & 2 \\
\hline Others & 1 & - & - & - & - & - & 1 \\
Glucose & 1 & 3 & 1 & - & 3 & 2 & 10 \\
Insulin & - & - & - & - & 1 & - & 1 \\
Glucagon & - & - & - & 1 & - & - & 1 \\
Dexamethasone & 1 & - & - & - & - & - & 1 \\
Bromocriptine & - & - & - & - & - & 1 & 1 \\
Levodopa & - & 1 & - & - & - & - & 1 \\
$\quad$ Chlorpromazine & - & & & & & & \\
\hline
\end{tabular}

$\mathrm{GnRH}$, gonadotropin releasing hormone; GRH, growth hormone releasing hormone; non-F, nonfunctioning tumor. 
induced apoplexy in occult pituitary macroadenomas [26, 27]. White et al. reported that the mechanism responsible probably involved an increase in intracellular glycoprotein subunit synthesis or vasoconstriction rather than a sudden increase in gonadotropin synthesis [28]. In the cases we reviewed, post-stimulation hormonal excess is most likely not responsible for the development of apoplexy, because of the high incidence of nonfunctioning tumors. The lack of an association between the time at which stimulated hormone release peaks and the time of onset of pituitary apoplexy also supports this. Abe et al. described two patients with non-functioning pituitary adenomas with apoplexy induced by hormonal stimulation, whose resected tumors had in situ DNA strand breaks, suggesting the presence of apoptotic cells [24].

The CAP testing is a screening test used in patients with suspected pituitary dysfunction. In our patient, because the basal concentrations of TSH and gonadotropins were suppressed while those of GH, PRL and ACTH were high, the CAP test was planned for preoperative estimation of the pituitary gland. Simultaneous administration of four hypothalamic releasing hormones and measurement of the release of target pituitary hormones permit the assessment of pituitary reserve in an ambulatory care setting [29]. TRH, $\mathrm{GnRH}$ and insulin are each capable of inducing apoplexy when administered alone $[7,9,12,14$, 24]. But in most cases it is difficult to determine which hormone caused the apoplexy, because the hormones are usually given in combination. Haakens et al. first reported a case of pituitary apoplexy associated with CAP testing of a nonfunctioning tumor [20]. In apoplexy caused by CAP testing, the effects of GRH and CRH should not be neglected, but there have been no reports of pituitary apoplexy caused by either GRH or CRH alone. Because $\mathrm{CRH}$ has begun to be used commonly, the potential for CRH to cause apoplexy should be investigated. In the present case, although the CAP testing was actually performed with only less than half of the regular doses, the apoplexy crisis occurred within 2 min. This finding indicates that the apoplexy which followed pituitary function testing may be independent of the administered doses. Based on the characteristics of our patient and our literature review, it appears that a common clinical feature of these cases is the increased size of the macroadenoma which often involves the suprasellar region. In our patient, radiographic findings indicated mild enlargement of the adenoma after CAP testing. Lever et al. described pituitary enlargement on $\mathrm{CT}$ examination after TRH injection [12], and Yada and Abe et al. also reported pituitary enlargement after $\mathrm{GnRH}$, TRH and insulin combined testing [17, 24]. These findings suggest that TRH may directly affect the intrasellar pressure. Among the other stimulants, the contribution of glucose or glucagon to apoplexy is unknown, but the fact that dexamethasone or bromocriptine alone caused apoplexy suggests that even the pituitary suppressive testing might affect the intrasellar pressure. Of 29 patients including ours, 22 were surgically treated and 7 patients were treated conservatively. Of the 7 patients, 5 had spontaneous remissions, 1 was treated with glucocorticoid and 1 received bromocriptine. Although 25 of the 29 patients $(87 \%)$ reported improvement, 4 patients (13\%) had persistent focal symptoms (amaurosis, aphasia, hemiparesis, etc.). To prevent life-threatening complications resulting from the endocrinologic examination, it is necessary to diagnose apoplexy quickly and determine if surgery is indicated. Bills et al. demonstrated that surgical treatment within a week of the onset of apoplexy resulted in significant recovery of visual acuity [1].

In summary, we described a patient with pituitary apoplexy induced by CAP testing with small doses. Our findings suggest that careful consideration of the benefit of CAP testing is necessary for all macroadenomas. Furthermore, I hope that the review of the reports of pituitary apoplexy caused by various stimulants will be helpful in clarifying the mechanism responsible for this complication. To evaluate dynamic pituitary function both non-invasively and precisely even in patients with suprasellar extension of the tumor, a new alternative testing method is desirable. 


\section{References}

1. Bills DC, Meyer FB, Laws ER, Davis DH, Ebersold MJ, Scheithauer BW, Ilstrup DM, Abboud CF (1993) A retrospective analysis of pituitary apoplexy. Neurosurgery 33: 602-609.

2. Reid RL, Quigley MW, Yen SSC (1985) Pituitary apoplexy. Arch Neurol 42: 712-719.

3. Dunn PJ, Donald RA, Espiner EA (1975) Regression of acromegaly following pituitary apoplexy. Aust NZ J Med 5: 369-372.

4. Silverman VE, Boyd AE, McCrary JA, Kohler PO (1978) Pituitary apoplexy following chlorpromazine stimulation. Arch Intern Med 138: 1738-1739.

5. Jordan RM, Cook DM, Kendall JW (1979) Nelson's syndrome and spontaneous pituitary tumor infarction. Arch Intern Med 139: 340-342.

6. Cimino A, Corsini R, Radaeli E, Bollati A, Giustina G (1981) Transient amaurosis in a patient with pituitary macroadenoma after intravenous gonadotropin and thyrotropin-releasing hormones. Lancet 11: 95.

7. Drury PL, Belchetz PE, McDonald WI, Thomas DGT, Besser GM (1982) Transient amaurosis and headache after thyrotropin-releasing hormone. Lancet 23: 218-219.

8. Bernstein M, Hegele RA, Gentili F, Brothers M, Holgate R, Sturtridge WC, Deck J (1984) Pituitary apoplexy associated with a triple bolus test. Case report. J Neurosurg 61: 586-590.

9. Korsic M, Lelas-Bahum B, Surdonja P, Besenski N, Horvat S, Plavsic V (1984) Infarction of FSHsecreting pituitary adenoma. Acta Endocrinol (Copenh) 107: 149-154.

10. Chapman AJ, Williams G, Hockley AD, London DR (1985) Pituitary apoplexy after combined test of anterior pituitary function. Br Med J 291: 26.

11. Yatsuzuka H, Kitajima T, Taguchi Y, Sakai H, Nakamura N (1986) A case of male cystic pituitary adenoma with hyperprolactinemia: Clinical study of six cases of male prolactinoma. No Shimkei Geka 14: 1601-1605 (In Japanese).

12. Lever EG, Butler J, Moore P, Cox TCS, Maccabe JJ (1986) Infarction of a growth hormone-secreting macroadenoma during a TRH test. Acta Endocrinol (Copenh) 112: 172-179.

13. Shirataki K, Chihara K, Shibata Y, Tamaki N, Matsumoto S, Fujita T (1988) Pituitary apoplexy manifested during a bromocriptine test in a patient with a growth hormone- and prolactin-producing pituitary adenoma. Neurosurgery 23: 395-398.

14. Harvey R, Michelagnoli M, McHenry P, Currie DG, Bewsher PD (1989) Pituitary apoplexy. Br Med J 298: 258.

15. Arafah BM, Taylor HC, Salazar R, Saadi H, Selman WR (1989) Apoplexy of a pituitary adenoma after dynamic testing with gonadotropin-releasing hormone. Am J Med 87: 103-105.

16. Kimura H, Fukushima $T$, Aikawa $H$, Takagi $T$, Tomonaga M (1989) Pituitary apoplexy in a child. Case report. Shoni no Noshinkei 14: 57-62 (In Japanese).

17. Yada O, Umezawa H, Miyake M (1992) Apoplexy of a pituitary macroadenoma after a triple test. Hormone to Rinsho 40: 124-127 (In Japanese).

18. Masson EA, Atkin SL, Diver M, White M (1993) Pituitary apoplexy and sudden blindness following the administration of gonadotropin releasing hormone. Clin Endocrinol (Copenh) 112: 172-179.

19. Fujiwara K, Owada $Y$, Kobayashi S, Ikeda H, Suzuki M, Yoshimoto T, Hanyu K (1993) A case of pituitary apoplexy diagnosed with MRI after endocrine test. Hormone to Rinsho 41: 157-161 (In Japanese).

20. Haakens K, Frey HM, Haug E (1994) Pituitary apoplexy after injection of pituitary-hormone releasing hormones. Tidsskr Nor Laegeforen 114(14): 1612-1613 (In Norwegian).

21. Vassalo M, Rana Z, Allen S (1994) Pituitary apoplexy after stimulation tests. Postgrad Med J 70: 444-445.

22. Frankart L, De Hertogh R, Donckier J, Gilliard C, Buysschaert M (1995) Pituitary apoplexy of a gonadotrophinoma and TRH/GnRH tests. Literature review. Acta Clin Belg 50(3): 163-170 (In French).

23. Masago A, Ueda $Y$, Kanai $H$, Nagai $H$, Umemura $S$ (1995) Pituitary apoplexy after pituitary function test: A report of two cases and review of the literature. Surg Neurol 43: 158-165.

24. Abe M, Shiraishi T, Nakagawa S, Tabuchi K (1995) Pituitary apoplexy and apoptosis. Hormone to Rinsho 43: 104-108 (In Japanese).

25. Scheithauer BW (1989) The pituitary and sellar region. In: Sternberg SS (ed) Diagnostic Surgical Pathology. New York, Raven Press, Ltd. 371-393.

26. Chanson P, Schaison G (1995) Pituitary apoplexy caused by GnRH-agonist treatment revealing gonadotroph adenoma. J Clin Endocrinol Metab 80(7): 2267-2268.

27. Ando S, Hoshino N, Mihara S (1995) Pituitary apoplexy after goserelin. Lancet 345: 458.

28. White MC, Masson EA (1994) Pituitary apoplexy following the administration of gonadotrophinreleasing hormone. Clin Endocrinol 41: 696-670.

29. Sheldon WR Jr, DeBold CR, Evans WS, DeCherney GS, Jackson RV, Island DP, Thorner MO, Orth DN (1985) Rapid sequential intravenous administration of four hypothalamic releasing hormones as a combined anterior pituitary function test in normal subjects. J Clin Endocrinol Metab 60: 623-630. 